\title{
Immigrants and tuberculosis in Hong Kong
}

\author{
CC Leung *, CK Chan, KC Chang, WS Law, SN Lee, LB Tai, Eric CC Leung, CM Tam
}

\section{A B S T R A C T}

Objective: To examine the impact of immigrant populations on the epidemiology of tuberculosis in Hong Kong.

Design: Longitudinal cohort study.

Setting: Hong Kong.

Participants: Socio-demographic and disease characteristics of all tuberculosis notifications in 2006 were captured from the statutory tuberculosis registry and central tuberculosis reference laboratory. Using 2006 By-census population data, indirect sex- and age-standardised incidence ratios by place of birth were calculated. Treatment outcome at 12 months was ascertained from government tuberculosis programme record forms, and tuberculosis relapse was tracked through the notification registry and death registry up to 30 June 2013.

Results: Moderately higher sex- and agestandardised incidence ratios were observed among various immigrant groups: 1.06 (Mainland China), 2.02 (India, Pakistan, Bangladesh), 1.59 (Philippines, Thailand, Indonesia, Nepal), and 3.11 (Vietnam). Recent Mainland migrants had a lower sex- and age-standardised incidence ratio (0.51 vs 1.09$)$ than those who immigrated 7 years ago or earlier. Age younger than 65 years, birth in the Mainland or the above Asian countries, and previous treatment were independently associated with resistance to isoniazid and/or rifampicin. Older age, birth in the above
Asian countries, non-permanent residents, previous history of treatment, and resistance to isoniazid and/ or rifampicin were independently associated with poor treatment outcome (other than cure/treatment completion) at 1 year. Birth outside Hong Kong was an independent predictor of relapse following successful completion of treatment (adjusted hazard ratio $=1.76 ; 95 \%$ confidence interval, 1.07-2.89; $\mathrm{P}=0.025)$.

Conclusion: Immigrants carry with them a higher tuberculosis incidence and/or drug resistance rate from their place of origin. The higher drug resistance rate, poorer treatment outcome, and excess relapse risk raise concern over secondary transmission of drug-resistant tuberculosis within the local community.

\section{Hong Kong Med J 2015;21:318-26}

DOI: $10.12809 / \mathrm{hkmj} 144492$

\section{Leung *, MB, BS, FHKAM (Medicine)}

CK Chan, MB, BS, FHKAM (Medicine)

KC Chang, MB, BS, FHKAM (Medicine)

WS Law, MB, ChB, FHKAM (Medicine)

SN Lee, MB, ChB, FHKAM (Medicine)

LB Tai, MB, ChB, FHKAM (Medicine)

ECC Leung, MB, BS, FHKAM (Medicine)

CM Tam, MB, BS, FHKAM (Medicine)

Tuberculosis and Chest Service, Department of Health, Wanchai Chest Clinic, 1/F, 99 Kennedy Road, Wanchai, Hong Kong

* Corresponding author: cc_leung@dh.gov.hk

New knowledge added by this study

- Immigrants carry with them a higher tuberculosis incidence and/or drug resistance rate from their place of origin to Hong Kong.

Implications for clinical practice or policy

- Their higher drug resistance rate, poorer treatment outcome, and excess relapse risk may increase the risk of secondary transmission of drug-resistant tuberculosis within the local community.

\section{Introduction}

Great disparity in tuberculosis (TB) rates has been reported in different parts of the world. ${ }^{1}$ Patients with TB from 22 high-burden areas accounted for over $80 \%$ of all notified TB cases in the world. ${ }^{1}$ Immigrants from these high-burden areas have often been blamed for their impact on the TB situation in many developed areas. ${ }^{2-12} \mathrm{~A}$ rapid increase in population was observed in Hong Kong in the last century, largely due to a heavy influx of immigrants from Mainland China. ${ }^{13-15}$ Despite remarkable socio-economic improvement over the past four decades, TB remains a common disease in Hong Kong. In 2006, the TB notification rate remained as high as $84.1 / 100000 .{ }^{16}$ With continuing population movement between the Mainland and Hong Kong, there has been major concern about cross-border transmission of infections including TB.

A large-scale population census has been conducted in Hong Kong every 10 years since 
1961, with a smaller by-census in-between. Tuberculosis is a statutorily notifiable disease, and basic demographic, clinical, and bacteriological data of notified cases are regularly captured by the TB notification registry. All residents are issued an identity card, and the identity card is used by both the TB notification registry and death registry as a unique personal identifier. Eighteen government chest clinics offer free programmatic case-finding and treatment services for TB patients under a centralised Tuberculosis and Chest Service of the Department of Health, with estimated programme coverage of over $80 \%$ of the population. Sputum culture and drug susceptibility testing are regularly performed by a centralised laboratory that is a Supranational Reference Laboratory within the World Health Organization/International Union Against Tuberculosis and Lung Diseases (WHO/ IUATLD) network. Standard short-course regimens are used in line with the WHO recommendations. Patients are regularly followed up for 2 years after initiation of TB treatment to facilitate cohort analysis of treatment outcome. Using regularly captured data within the statutory registries and government TB programme, a longitudinal cohort study was performed to examine the impact of immigrant populations on the epidemiology of $\mathrm{TB}$ in Hong Kong.

\section{Methods}

Data on sex, age, place of birth, residency status, case category (new or retreatment), disease form (pulmonary with or without extrapulmonary involvement, or extrapulmonary only), sputum smear and culture results of consecutive patients notified within 2006 were obtained from the territory-wide TB notification registry of Hong Kong. An active case of TB was defined as positive isolation of Mycobacterium tuberculosis complex or, in the case of absent bacteriological confirmation, disease diagnosed on clinical, radiological, and/or histological grounds together with an appropriate response to anti-TB treatment. As part of the public health surveillance, bacteriological results of notified cases were verified with the reports from the central TB reference laboratory, with drug susceptibility test results for streptomycin, isoniazid, rifampicin, and ethambutol retrieved for culture-positive cases.

The sex- and age-stratified population data were obtained from the 2006 By-census for the following places of birth: Hong Kong (Group I); Mainland China (Group II); India, Pakistan, and Bangladesh (Indian subcontinent: Group III); Philippines, Thailand, Indonesia, and Nepal (other key Asian minority groups, Group IV); Vietnam (Group V); and other miscellaneous places of birth (Group VI). ${ }^{17}$ The crude incidence of TB among each of the above population groups was calculated with

\section{香港移民與結核病}

\section{梁子超、陳志權、鄭國釗、羅穎思、李淑娜、戴麗文、 梁中正、譚卓明}

目的：研究移民人口對於香港結核病流行病學的影響。

設計：縱向隊列研究。

安排：香港。

參與者：根據法定的結核病通報資料庫和中央結核病參考實驗室中選 取2006年所有結核病呈報病例的人口學和疾病特徵資料。採用2006年 中期人口統計數據, 按其出生地來計算間接的性別和年齡標準化發病 率。從政府的結核病計劃紀錄確定患者 12 個月後的治療結果, 再透過 結核病通報資料庫以及死亡登記處的紀錄追踪至 2013 年6月30日以確 定是否有復發病例。

結果 : 不同移民群體的性別和年齡標準化結核病發病率都偏高 : 1.06 (中國大陸）、2.02（印度、巴基斯坦、孟加拉）、1.59（菲律 賓、泰國、印度尼西亞、尼泊爾）和3.11（越南）。中國大陸新 移民的性別和年齡標準化結核病發病率較 7 年前或更早期的移民 低, 分別為 0.51 比 $1.09 \circ 65$ 歲以下、於內地或以上提及的亞洲國 家出生, 以及曾接受結核病治療都是異煙肼和/或利福平耐藥性 的獨立相關因素。年紀較大、於以上提及的亞洲國家出生、非永 久居民、曾接受結核病治療和異煙肼和/或利福平耐藥性都是 1 年 後有較差治療結果（並未康復或完成治療）的獨立相關因素。此 外, 在香港以外地方出生是成功治療後出現復發的獨立預測因素 （調整後危險比 $=1.76 ； 95 \%$ 置信區間：1.07-2.89；P=0.025）。

結論：移民人口會隨着他們的原籍地方帶來較高的結核病發病率和/或 耐藥性。較高的耐藥性比率、較差的治療結果和較高復發率引起對社 區內耐藥性結核病二次傳播的關注。

adjustment made by a multiplication factor (total notified cases / [total notified cases - cases with missing place of birth]) for cases with missing data on place of birth. The sex- and age-specific (by 5 -year age-group) TB rates were derived from the overall population data and applied to the corresponding sex-age groups of each of the above six population groups to obtain the expected number of cases. The observed number of TB cases for each population group was compared with the respective number of expected cases to obtain the indirectly standardised TB incidence ratio. The 95\% confidence intervals (CIs) were calculated by assuming a Poisson distribution in the occurrence of events. For those born in Mainland China, further stratification was made by the duration of residence in Hong Kong.

The treatment outcome 12 months after initiation of treatment was ascertained for those patients being managed by the government chest clinics under the Tuberculosis and Chest Service from the programme record form of the Tuberculosis and Chest Service. Treatment success was defined as cure or treatment completion (successfully completed treatment of $\geq 6$ months for new cases 
and $\geq 8$ months for retreatment cases), irrespective of subsequent relapse or death or loss to follow-up. All other treatment outcomes (including death before treatment completion, default, transferring out, still on treatment at 12 months after treatment initiation) were regarded as unsuccessful. Permanent residents who successfully completed treatment under the government TB programme were subsequently tracked up to 30 June 2013 through the territorywide TB notification registry and death registry for relapse of TB or death.

Chi squared and Fisher's exact tests were used as appropriate for categorical variables and analysis of variance was used for continuous variables. Logistic regression modelling was used for multivariate analysis of 12-month outcome. For censored data of TB relapse during follow-up, Kaplan-Meier analysis was used in univariate analysis and Cox proportional hazards modelling was used in multivariate analysis to adjust for potential confounders. A two-tailed P value of 0.05 was considered statistically significant.

The study was part of a public health surveillance exercise in tracking the profile and outcome of statutory TB notifications. It did not involve intervention on human subjects.

\section{Results}

A total of 6246 TB notifications were received in 2006, 480 of which were excluded because of duplicate notification or revised diagnosis, leaving 5766 cases in the 2006 TB notification registry.
Of these, 18 cases involving tourists, 17 cases involving illegal immigrants, and 329 cases without information on place of birth were also excluded, leaving 5402 cases for analysis. Table 1 shows their basic characteristics as stratified by place of birth. The vast majority (92.3\%) of TB cases involved residents born in either Hong Kong or Mainland China. Significant differences were observed between the six population groups in terms of sex and age distribution as well as proportions of new and pulmonary cases, but not proportions of either smear-positive or culture-confirmed cases.

Table 2 summarises the incidence of TB and indirectly sex- and age-standardised incidence ratio (SIR) of TB for the six population groups. The TB SIR was significantly above 1 for those born in Mainland China (males and combined), Group III (females and combined), Group IV (females and combined), and Group V (males and combined), but significantly below 1 for those born in Hong Kong (males, females, and combined) and other miscellaneous places of birth (males, females, and combined). Mainlandborn permanent residents (staying in Hong Kong for $\geq 7$ years) maintained a higher TB risk than the population average for both sexes and combined. Nonetheless, recent Mainland immigrants with duration of stay of less than 7 years actually had a lower TB risk than the general population, despite sex and age standardisation.

Table 3 shows the resistance profile of 3474 (98.1\%) culture-confirmed cases (with available drug susceptibility testing results) by place of birth. Table

TABLE I. Basic characteristics of tuberculosis cases notified in 2006 in Hong Kong as stratified by place of birth

\begin{tabular}{lccccccc}
\hline Characteristic & \multicolumn{5}{c}{ Group No. ${ }^{*}$, No. (\%) } & \multicolumn{1}{c}{ P value } \\
\cline { 2 - 6 } & I (n=2138) & II (n=2846) & III (n=38) & IV (n=284) & V (n=30) & VI (n=66) & Overall \\
(n=5402†)
\end{tabular}


TABLE 2. Annual incidences of active tuberculosis (all forms) in resident population by place of birth in 2006

\begin{tabular}{|c|c|c|c|c|c|}
\hline Place of birth & Sex & Population & $\begin{array}{c}\text { Observed TB } \\
\text { cases }\end{array}$ & $\begin{array}{c}\text { Incidence* }(95 \% \mathrm{Cl}) \\
\text { per } 100000 \text {-year }\end{array}$ & SIR $^{\star}$ \\
\hline \multirow[t]{3}{*}{ I. Hong Kong } & Female & 2039064 & 770 & $40.0(37.3-42.7)$ & $0.87(0.82-0.93)$ \\
\hline & Male & 2099780 & 1368 & $69.2(65.7-72.6)$ & $0.92(0.88-0.97)$ \\
\hline & Both & 4138844 & 2138 & $54.8(52.6-57.0)$ & $0.90(0.87-0.94)$ \\
\hline \multicolumn{6}{|l|}{ II. Mainland } \\
\hline \multirow[t]{3}{*}{ Permanent resident } & Female & 997765 & 774 & 82.6 (77.0-88.3) & $1.08(1.00-1.15)$ \\
\hline & Male & 943370 & 2011 & 216.5 (216.5-235.6) & $1.10(1.05-1.14)$ \\
\hline & Both & 1941135 & 2785 & $152.3(146.8-157.8)$ & $1.09(1.05-1.13)$ \\
\hline \multirow[t]{3}{*}{$<7$ Years of stay } & Female & 192718 & 44 & $24.2(17.2-31.1)$ & $0.52(0.37-0.67)$ \\
\hline & Male & 81927 & 17 & $22.0(11.8-32.2)$ & $0.50(0.27-0.73)$ \\
\hline & Both & 274645 & 61 & $23.5(17.8-29.3)$ & $0.51(0.39-0.64)$ \\
\hline \multirow[t]{3}{*}{ All residency status } & Female & 1190483 & 818 & 73.2 (68.5-77.9) & $1.02(0.95-1.08)$ \\
\hline & Male & 1025297 & 2028 & $209.5(200.8-218.1)$ & $1.08(1.04-1.13)$ \\
\hline & Both & 2215780 & 2846 & $136.2(131.5-141.0)$ & $1.06(1.03-1.10)$ \\
\hline \multirow[t]{3}{*}{ III. Indian subcontinent (India, Pakistan, Bangladesh) } & Female & 12458 & 20 & $169.9(99.5-240.2)$ & $3.11(1.82-4.40)$ \\
\hline & Male & 13259 & 18 & $144.0(81.2-206.7)$ & $1.45(0.82-2.08)$ \\
\hline & Both & 25717 & 38 & 156.5 (109.5-203.5) & $2.02(1.41-2.62)$ \\
\hline \multirow[t]{3}{*}{ IV. Philippines, Indonesia, Thailand, and Nepal } & Female & 240168 & 239 & $105.5(92.9-118.1)$ & $1.82(1.60-2.03)$ \\
\hline & Male & 29661 & 45 & $161.0(116.7-205.3)$ & $0.96(0.70-1.23)$ \\
\hline & Both & 269829 & 284 & $111.6(99.4-123.9)$ & $1.59(1.42-1.77)$ \\
\hline \multirow[t]{3}{*}{ V. Vietnam } & Female & 6463 & 8 & $130.7(45.0-216.5)$ & $2.01(0.69-3.33)$ \\
\hline & Male & 4031 & 22 & $590.5(362.2-818.4)$ & $3.86(2.37-5.34)$ \\
\hline & Both & 10494 & 30 & $307.3(205.0-409.6)$ & $3.11(2.07-4.14)$ \\
\hline \multirow[t]{3}{*}{ VI. Miscellaneous } & Female & 102754 & 22 & $22.8(13.9-31.8)$ & $0.43(0.26-0.60)$ \\
\hline & Male & 100928 & 44 & $46.4(33.5-59.3)$ & $0.41(0.30-0.53)$ \\
\hline & Both & 203682 & 66 & 34.5 (26.7-42.3) & $0.42(0.32-0.52)$ \\
\hline \multirow[t]{3}{*}{ Overall† } & Female & 3591390 & 1993 & 55.5 (53.1-57.9) & - \\
\hline & Male & 3272956 & 3738 & $114.2(110.5-117.9)$ & - \\
\hline & Both & 6864346 & 5731 & 83.5 (81.3-85.7) & - \\
\hline
\end{tabular}

Abbreviations: $\mathrm{Cl}=$ confidence interval; $\mathrm{SIR}=$ sex- and age-standardised incidence ratio; $\mathrm{TB}=$ tuberculosis

* Adjustment made by proportional allocation of 329 cases with unknown places of birth to each birth group through the application of a multiplication factor (total notified cases / [total notified cases - cases with missing place of birth])

† Including 329 cases with unknown places of birth

4 summarises the results of univariate and multiple resistance.

logistic analyses with respect to isoniazid, rifampicin, Of the 5402 subjects included in this study, 4319 and multidrug resistance (resistance to both isoniazid (80.0\%) were managed, at least at some stage of the and rifampicin) of 3434 culture-confirmed cases disease, within the government TB programme. A after combining all patients born in Asian countries total of 3304 (76.5\%) patients successfully completed listed under Groups III, IV and V, and excluding 40 treatment within 12 months after initiation of patients with miscellaneous places of birth in Group treatment. Table 5 summarises the factors associated VI that included very few drug-resistant cases. In the with 12-month treatment outcome in both univariate multiple logistic regression models using a backward analysis and multivariate logistic regression analysis. stepwise elimination approach, only age $<65$ years, Of those patients who successfully completed place of birth, and history of previous treatment (ie treatment, 3176 (96.1\%) permanent residents in retreatment cases) remained important independent Hong Kong were followed up by cross-linking with predictors of isoniazid, rifampicin, and multidrug the TB notification registry and death registry until 
TABLE 3. Resistance to first-line drugs by place of birth

\begin{tabular}{|c|c|c|c|c|c|c|c|}
\hline \multirow{2}{*}{$\begin{array}{l}\text { Drug susceptibility } \\
\text { test }\end{array}$} & \multicolumn{6}{|c|}{ Group No.*, No. (\%) } & \multirow[t]{2}{*}{ Overall } \\
\hline & $\mathbf{I}$ & II & III & IV & $\mathbf{v}$ & VI & \\
\hline All & $(n=1362)$ & $(n=1864)$ & $(n=23)$ & $(n=163)$ & $(n=22)$ & $(n=40)$ & $(n=3474 \dagger)$ \\
\hline Fully sensitive & $1231(90.4)$ & $1706(91.5)$ & $19(82.6)$ & $147(90.2)$ & $15(68.2)$ & $34(85.0)$ & $3152(90.7)$ \\
\hline S-resistant & $102(7.5)$ & $105(5.6)$ & $1(4.3)$ & $2(1.2)$ & $5(22.7)$ & $4(10.0)$ & $219(6.3)$ \\
\hline H-resistant & $57(4.2)$ & $83(4.5)$ & $4(17.4)$ & $13(8.0)$ & $6(27.3)$ & $2(5.0)$ & $165(4.7)$ \\
\hline R-resistant & $11(0.8)$ & $20(1.1)$ & 0 & $5(3.1)$ & $1(4.5)$ & 0 & $37(1.1)$ \\
\hline M-resistant & $8(0.6)$ & $11(0.6)$ & 0 & $1(0.6)$ & $1(4.5)$ & 0 & $21(0.6)$ \\
\hline MDR & $5(0.4)$ & $17(0.9)$ & 0 & $2(1.2)$ & $1(4.5)$ & 0 & $25(0.7)$ \\
\hline New & $(n=1235)$ & $(n=1668)$ & $(n=21)$ & $(n=155)$ & $(n=18)$ & $(n=37)$ & $(n=3134)$ \\
\hline Fully sensitive & $1117(90.4)$ & $1540(92.3)$ & $17(81.0)$ & $140(90.3)$ & $13(72.2)$ & $31(83.8)$ & $2858(91.2)$ \\
\hline S-resistant & $92(7.4)$ & $86(5.2)$ & $1(4.8)$ & $1(0.6)$ & $3(16.7)$ & $4(10.8)$ & $187(6.0)$ \\
\hline H-resistant & $49(4.0)$ & $62(3.7)$ & $4(19.0)$ & $12(7.7)$ & $4(22.2)$ & $2(5.4)$ & $133(4.2)$ \\
\hline R-resistant & $9(0.7)$ & $15(0.9)$ & 0 & $4(2.6)$ & 0 & 0 & $28(0.9)$ \\
\hline M-resistant & $7(0.6)$ & $9(0.5)$ & 0 & 0 & 0 & 0 & $16(0.5)$ \\
\hline MDR & $3(0.2)$ & $12(0.7)$ & 0 & $1(0.6)$ & 0 & 0 & $16(0.5)$ \\
\hline Retreatment & $(n=127)$ & $(n=196)$ & $(n=2)$ & $(n=8)$ & $(n=4)$ & $(n=3)$ & $(n=340)$ \\
\hline Fully sensitive & $114(89.8)$ & $166(84.7)$ & $2(100.0)$ & 7 (87.5) & $2(50.0)$ & $3(100.0)$ & $294(86.5)$ \\
\hline S-resistant & $10(7.9)$ & $19(9.7)$ & 0 & $1(12.5)$ & $2(50.0)$ & 0 & $32(9.4)$ \\
\hline H-resistant & $8(6.3)$ & $21(10.7)$ & 0 & $1(12.5)$ & $2(50.0)$ & 0 & $32(9.4)$ \\
\hline R-resistant & $2(1.6)$ & $5(2.6)$ & 0 & $1(12.5)$ & $1(25.0)$ & 0 & $9(2.6)$ \\
\hline M-resistant & $1(0.8)$ & $2(1.0)$ & 0 & $1(12.5)$ & $1(25.0)$ & 0 & $5(1.5)$ \\
\hline MDR & $2(1.6)$ & $5(2.6)$ & 0 & $1(12.5)$ & $1(25.0)$ & 0 & $9(2.6)$ \\
\hline
\end{tabular}

Abbreviations: $\mathrm{H}=$ isoniazid; $\mathrm{M}=$ ethambutol; $\mathrm{MDR}=$ multidrug-resistant; $\mathrm{R}=$ rifampicin; $\mathrm{S}=$ streptomycin

* I: Hong Kong; II: Mainland China; III: Indian subcontinent (India, Pakistan, and Bangladesh); IV: Other key Asian groups (Philippines, Indonesia, Thailand, and Nepal); $V: V i e t n a m ; \bigvee l:$ Miscellaneous

† Excluding 67 culture-confirmed cases without drug sensitivity results

relapse of TB, death or 30 June 2013, whichever was the earliest. After a mean ( \pm standard deviation) duration of $5.28 \pm 1.64$ years of follow-up, $80(2.5 \%)$ relapses were detected at a median (range) time interval of 1004 (225-2640) days after initiation of treatment, 37 (46.3\%) of which were bacteriologically confirmed. In Kaplan-Meier analysis, the relapse risk was higher among permanent residents born outside Hong Kong than among those born in Hong Kong ( $3.0 \%$ vs $1.9 \%$; log rank test, $\mathrm{P}=0.019)$. A consistently higher relapse risk was present among those born outside Hong Kong (adjusted hazard ratio=1.76; 95\% CI, 1.07-2.89; $\mathrm{P}=0.025)$ after adjustment for gender, age, case category (new or retreatment), type of TB (pulmonary or extrapulmonary only), sputum smear, culture, and drug resistance to isoniazid and/ or rifampicin at the baseline. The Figure shows the cumulative hazard curves by place of birth in and outside Hong Kong in Cox proportional hazards modelling.

\section{Discussion}

In this study, persons born in Hong Kong had a SIR of 0.90 (95\% CI, 0.87-0.94), while those born in Mainland China (Group II), Indian subcontinent (Group III), Philippines, Indonesia, Thailand, Nepal (Group IV), and Vietnam (Group V) had significantly higher SIRs of 1.06, 2.02, 1.59, and 3.11 respectively (Table 2). Recent Mainland migrants (with length of stay $<7$ years), however, had a significantly lower SIR (0.51 vs 1.09) than other Mainlandborn residents. Age <65 years, birth in Mainland or Groups III-V Asian countries, and history of previous treatment were independently associated with resistance to isoniazid and/or rifampicin (Table 4). Older age, birth in Groups III-V Asian countries, non-permanent residents, retreatment case, and resistance to isoniazid and/or rifampicin were independently associated with lower treatment success (cure/treatment completion) rate at 1 year 
TABLE 4. Factors affecting isoniazid, rifampicin, and multidrug resistance at baseline*

\begin{tabular}{|c|c|c|c|c|c|}
\hline \multirow[t]{2}{*}{ Factor } & \multirow[t]{2}{*}{ Category } & \multicolumn{2}{|c|}{ Univariate analysis } & \multicolumn{2}{|c|}{ Multivariate analysis } \\
\hline & & Resistance, No. (\%) & $P$ value & Adjusted OR (95\% CI) & $P$ value \\
\hline \multicolumn{6}{|l|}{ Isoniazid } \\
\hline \multirow[t]{2}{*}{ Sex } & Female & $50(4.6)$ & 0.827 & - & - \\
\hline & Male & $113(4.8)$ & & & \\
\hline \multirow[t]{2}{*}{ Age (years) } & $<65$ & $110(5.7)$ & 0.004 & Reference & 0.003 \\
\hline & $\geq 65$ & $53(3.6)$ & & $0.57(0.39-0.83)$ & \\
\hline \multirow[t]{4}{*}{ Place of birth } & & & $<0.001$ & & $<0.001$ \\
\hline & Hong Kong & $57(4.2)$ & & Reference & \\
\hline & Mainland & $83(4.5)$ & & $1.32(0.91-1.91)$ & \\
\hline & Asian countries $\ddagger$ & $23(11.1)$ & & $2.78(1.67-4.64)$ & \\
\hline \multirow[t]{2}{*}{ Permanent residency } & No & $17(9.8)$ & 0.001 & - & - \\
\hline & Yes & $146(4.5)$ & & & \\
\hline \multirow[t]{2}{*}{ Case category } & New & $131(4.2)$ & $<0.001$ & Reference & $<0.001$ \\
\hline & Retreatment & $32(9.5)$ & & $2.67(1.77-4.02)$ & \\
\hline \multicolumn{6}{|l|}{ Rifampicin } \\
\hline \multirow[t]{2}{*}{ Sex } & Female & $11(1.0)$ & 0.821 & - & - \\
\hline & Male & $26(1.1)$ & & & \\
\hline \multirow[t]{2}{*}{ Age (years) } & $<65$ & $27(1.4)$ & 0.043 & Reference & 0.019 \\
\hline & $\geq 65$ & $10(0.7)$ & & $0.39(0.17-0.86)$ & \\
\hline \multirow[t]{4}{*}{ Place of birth } & & & 0.026 & & 0.045 \\
\hline & Hong Kong & $11(0.8)$ & & Reference & \\
\hline & Mainland & $20(1.1)$ & & $1.86(0.85-4.07)$ & \\
\hline & Asian countriesł & $6(2.9)$ & & $3.48(1.27-9.58)$ & \\
\hline \multirow[t]{2}{*}{ Permanent residency } & No & $5(2.9)$ & $0.037 \S$ & - & - \\
\hline & Yes & $32(1.0)$ & & & \\
\hline \multirow[t]{2}{*}{ Case category } & New & $28(0.9)$ & $0.008 \S$ & Reference & 0.001 \\
\hline & Retreatment & $9(2.7)$ & & $3.52(1.63-7.60)$ & \\
\hline \multicolumn{6}{|l|}{ Multidrug } \\
\hline \multirow[t]{2}{*}{ Sex } & Female & $7(0.6)$ & 0.709 & - & - \\
\hline & Male & $18(0.8)$ & & & \\
\hline \multirow[t]{2}{*}{ Age (years) } & $<65$ & $17(0.9)$ & 0.249 & Reference & 0.031 \\
\hline & $\geq 65$ & $8(0.5)$ & & $0.37(0.15-0.91)$ & \\
\hline \multirow[t]{4}{*}{ Place of birth } & & & 0.047 & & 0.047 \\
\hline & Hong Kong & $5(0.4)$ & & Reference & \\
\hline & Mainland & $17(0.9)$ & & $3.48(1.23-9.85)$ & \\
\hline & Asian countriesł & $3(1.4)$ & & $3.91(0.92-16.62)$ & \\
\hline \multirow[t]{2}{*}{ Permanent residency } & No & $3(1.7)$ & $0.130 \S$ & - & - \\
\hline & Yes & $22(0.7)$ & & & \\
\hline \multirow[t]{2}{*}{ Case category } & New & $16(0.5)$ & $<0.001 \S$ & Reference & $<0.001$ \\
\hline & Retreatment & $9(2.7)$ & & $6.00(2.60-13.85)$ & \\
\hline
\end{tabular}

Abbreviations: $\mathrm{Cl}=$ confidence interval; $\mathrm{OR}=$ odds ratio

* Including 3434 patients in Groups I to $\vee$ with drug susceptibility results; 40 patients with miscellaneous place of birth excluded

+ Predictor variables initially entered included gender, age, retreatment case, place of birth and permanent residency, but only age, place of birth, and retreatment case remained in final model; gender and permanent residency excluded from final model because $P>0.10$

‡ Groups III, IV, and V combined (India, Pakistan, Bangladesh, Philippines, Thailand, Indonesia, Nepal, and Vietnam)

$\S$ Fisher's exact test, two-sided $P$ value 
TABLE 5. Treatment outcome of 4319 patients in government tuberculosis programme at 12 months after initiation of treatment

\begin{tabular}{|c|c|c|c|c|c|}
\hline Variable & Category & $\begin{array}{c}\text { Treatment } \\
\text { success rate }(\%)\end{array}$ & $P$ value & Adjusted odds ratio* & $P$ value \\
\hline \multirow[t]{2}{*}{ Gender } & Female & 76.3 & 0.831 & Reference & 0.406 \\
\hline & Male & 76.6 & & $0.93(0.79-1.10)$ & \\
\hline \multirow[t]{5}{*}{ Age-group (years) } & & & $<0.001$ & & $<0.001$ \\
\hline & $0-14$ & 90.3 & & $1.84(0.55-6.17)$ & \\
\hline & $15-34$ & 79.9 & & Reference & \\
\hline & $35-64$ & 78.0 & & $0.75(0.61-0.93)$ & \\
\hline & $\geq 65$ & 72.2 & & $0.51(0.40-0.64)$ & \\
\hline \multirow[t]{5}{*}{ Place of birth } & & & $<0.001$ & & 0.021 \\
\hline & Hong Kong & 80.0 & & Reference & \\
\hline & Mainland & 75.8 & & $1.00(0.85-1.19)$ & \\
\hline & Asian countries $†$ & 58.1 & & $0.56(0.38-0.82)$ & \\
\hline & Miscellaneous & 76.3 & & $1.04(0.55-1.94)$ & \\
\hline \multirow[t]{2}{*}{ Permanent residency } & No & 55.5 & $<0.001$ & Reference & $<0.001$ \\
\hline & Yes & 77.7 & & $2.50(1.67-3.74)$ & \\
\hline \multirow[t]{2}{*}{ Case category } & New & 77.2 & 0.002 & Reference & 0.015 \\
\hline & Retreatment & 71.0 & & $0.77(0.62-0.95)$ & \\
\hline \multirow[t]{2}{*}{ Type } & Pulmonary & 76.7 & 0.325 & Reference & 0.443 \\
\hline & Extrapulmonary & 74.6 & & $0.90(0.70-1.17)$ & \\
\hline \multirow[t]{2}{*}{ Sputum smear } & Negative & 76.6 & 0.882 & Reference & 0.924 \\
\hline & Positive & 76.4 & & $0.99(0.84-1.22)$ & \\
\hline \multirow[t]{2}{*}{ Culture-confirmed } & Negative & 76.9 & 0.656 & Reference & 0.733 \\
\hline & Positive & 76.3 & & $1.03(0.87-1.22)$ & \\
\hline \multirow[t]{2}{*}{ Drug resistance $\ddagger$} & No & 77.4 & $<0.001$ & Reference & $<0.001$ \\
\hline & Yes & 62.4 & & $0.47(0.36-0.61)$ & \\
\hline
\end{tabular}

* Multiple logistic regression, adjusted for all other variables as shown

† Groups III-V combined: India, Pakistan, Bangladesh, Philippines, Thailand, Indonesia, Nepal, and Vietnam

‡ Isoniazid and/or rifampicin resistance

(Table 5). Birth outside Hong Kong (Groups II-V combined) was an independent predictor of TB relapse among permanent residents after successful treatment completion under the government TB programme (Fig).

With the successful control of recent transmission of TB in Hong Kong, the majority of TB cases arose from endogenous reactivation of past infection. ${ }^{18}$ The higher SIR and drug resistance prevalence among Mainland immigrants and immigrants from Groups III-V Asia countries corroborate reports of higher $\mathrm{TB}$ incidence ${ }^{2-6,8}$ and drug resistance 7,12 among immigrants in lowTB-burden countries. These higher risks among immigrants may have resulted at least in part from reactivation of latent $\mathrm{TB}$ infection ${ }^{9-11}$ acquired during their previous residence in, and/or travel to, their places of birth with higher burdens of TB and/ or drug resistance. ${ }^{1,19-22}$ Apart from possible selection factors in migration, the progressive fall in TB prevalence in the Mainland over the recent decades ${ }^{22}$ could also have contributed to a lower burden of latent $\mathrm{TB}$ infection, and hence SIR, among recent Mainland immigrants compared with those who immigrated longer ago. Taking into consideration the independent effects of birth outside Hong Kong on both treatment outcome and relapse (Table 5 and Fig), population mobility may have adversely affected treatment adherence, and thus impacted on treatment outcome and/or relapse with possible acquisition of drug resistance. In line with these observations, a previous case-control study also identified younger age, non-permanent residents, and frequent travel as independent predictors of multidrug-resistant TB among previously treated patients in Hong Kong. ${ }^{23}$

Although this study showed an increased risk of TB among immigrants in Hong Kong, which is a 
metropolitan city with intermediate TB burden, the vast majority of TB cases still occurred among the majority population groups of local-born persons or permanent residents born in Mainland China (both of which were largely of Chinese ethnicity). This is contrary to the situation in most low-burden areas, where the majority of $\mathrm{TB}$ cases often came from foreign-born minority groups..$^{2,3,12}$ The relatively high crude TB incidence rate of 55/100000, even among the local-born (both genders combined) in this intermediate burden area (Table 2), could have reduced the risk differential between the immigrant groups and the local-born, thus reducing the influence of immigrants on the overall TB incidence. Nonetheless, the higher drug resistance rate, poorer treatment outcome, and higher relapse rate among immigrants in this study remain critical areas of concern. In a recent study on the transmission of drug-resistant TB in Hong Kong, ${ }^{24}$ $46 \%$ of all multidrug-resistant $\mathrm{TB}$ cases were new cases with no previous history of treatment. This suggests ongoing transmission of these difficult-totreat $\mathrm{TB}$ cases within our community. The degree of molecular clustering was as high as $65 \%$ among extensively drug-resistant TB cases, the majority of which did not have obvious epidemiological linkage, suggesting active transmission outside households or other conventional close contact settings. ${ }^{24}$

This study was based on territory-wide data from by-census, statutory registries, a centralised government TB programme, and centralised TB laboratory. The well-developed health care infrastructure in Hong Kong with easy access to free TB care services allowed capture of relevant information from TB patients notified in a bycensus year and successful tracking of the majority of them for treatment outcome and relapse. Some degree of incomplete case ascertainment was still likely as in all other public health surveillance systems. Even though around $20 \%$ of the notified patients were managed outside the government TB programme, this might not have substantially confounded the internal comparisons among different population groups if access to care could be assumed to be roughly parallel. If the usual inverse care law ${ }^{25}$ did apply, the direction of bias would likely be underestimation of the risks among the immigrants as an underprivileged group. With the limited amount of socio-demographic and clinical information contained in the various statutory registries and programme forms, this study may not be in a strong position to analyse the complex mechanisms that underlie the observed associations between immigrants and treatment outcome or relapse. Further studies are therefore warranted to identify potential areas of intervention for specific minority groups.

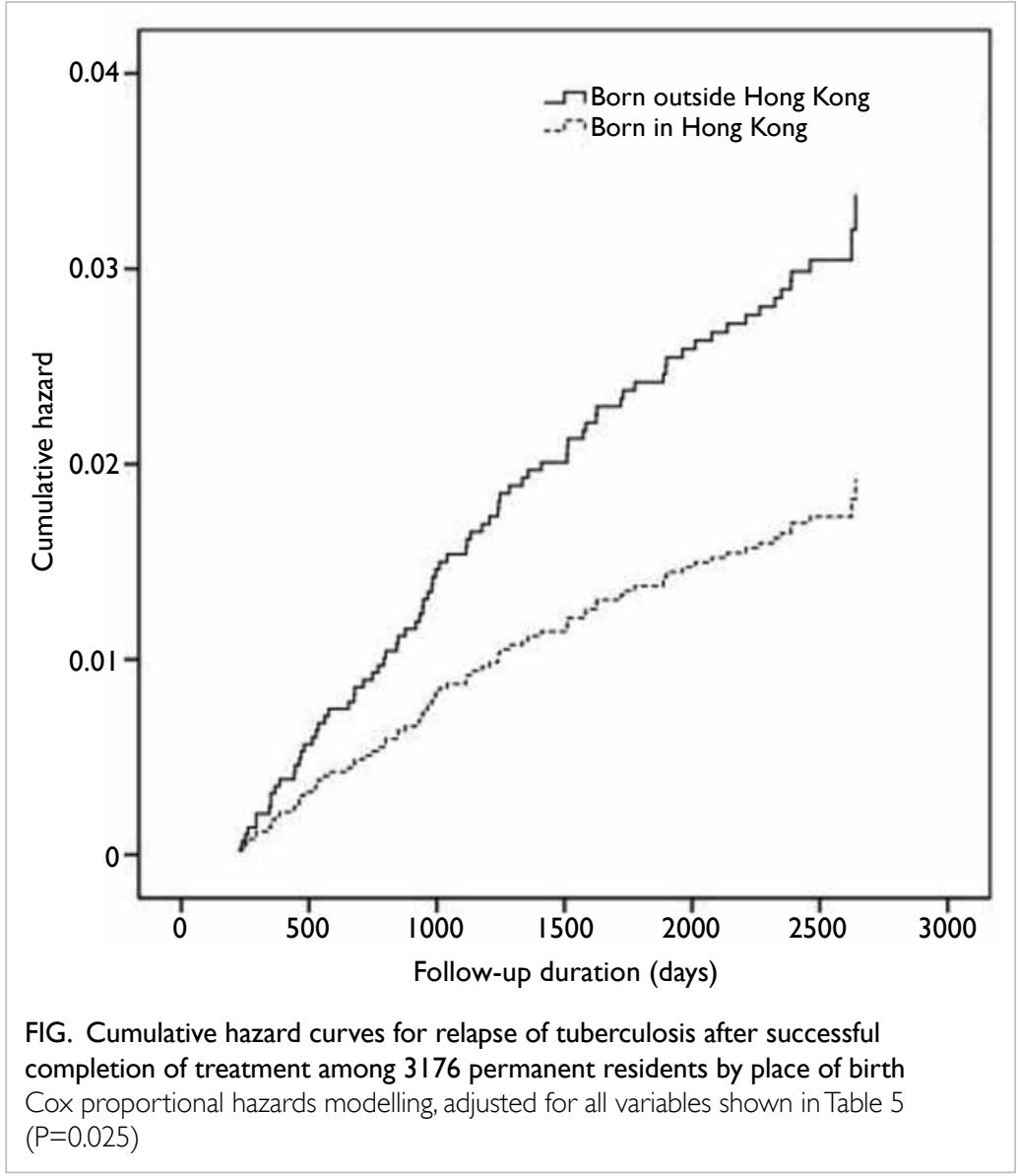

\section{Declaration}

No external grant or support has been received for this study.

\section{References}

1. Global tuberculosis control report 2013. WHO/HTM/ TB/2013.11. Available from: http://apps.who.int/iris/ bitstream/10665/91355/1/9789241564656_eng.pdf. Accessed May 2015.

2. Gilbert RL, Antoine D, French CE, Abubakar I, Watson JM, Jones JA. The impact of immigration on tuberculosis rates in the United Kingdom compared with other European countries. Int J Tuberc Lung Dis 2009;13:645-51.

3. Das D, Baker M, Venugopal K, McAllister S. Why the tuberculosis incidence rate is not falling in New Zealand. N Z Med J 2006;119:U2248.

4. Cain KP, Haley CA, Armstrong LR, et al. Tuberculosis among foreign-born persons in the United States: achieving tuberculosis elimination. Am J Respir Crit Care Med 2007;175:75-9.

5. Dye C, Lönnroth K, Jaramillo E, Williams BG, Raviglione $M$. Trends in tuberculosis incidence and their determinants in 134 countries. Bull World Health Organ 2009;87:683-91.

6. Svensson E, Millet J, Lindqvist A, et al. Impact of immigration on tuberculosis epidemiology in a low- 
incidence country. Clin Microbiol Infect 2011;17:881-7.

7. Baussano I, Mercadante S, Pareek M, Lalvani A, Bugiani M. High rates of Mycobacterium tuberculosis among socially marginalized immigrants in low-incidence area, 1991-2010, Italy. Emerg Infect Dis 2013;19:1437-45.

8. Manangan L, Elmore $\mathrm{K}$, Lewis $\mathrm{B}$, et al. Disparities in tuberculosis between Asian/Pacific Islanders and nonHispanic Whites, United States, 1993-2006. Int J Tuberc Lung Dis 2009;13:1077-85.

9. Farah MG, Meyer HE, Selmer R, Heldal E, Bjune G. Longterm risk of tuberculosis among immigrants in Norway. Int J Epidemiol 2005;34:1005-11.

10. Patel S, Parsyan AE, Gunn J, et al. Risk of progression to active tuberculosis among foreign-born persons with latent tuberculosis. Chest 2007;131:1811-6.

11. McPherson ME, Kelly H, Patel MS, Leslie D. Persistent risk of tuberculosis in migrants a decade after arrival in Australia. Med J Aust 2008;188:528-31.

12. Long R, Langlois-Klassen D. Increase in multidrugresistant tuberculosis (MDR-TB) in Alberta among foreignborn persons: implications for tuberculosis management. Can J Public Health 2013;104:e22-7.

13. Tuberculosis and Chest Service. Annual Report of Tuberculosis and Chest Service 1949. Hong Kong: Department of Health; 1950: 3.

14. Tuberculosis and Chest Service. Annual Report of Tuberculosis and Chest Service 1961. Hong Kong: Department of Health; 1962: 3.

15. Hong Kong Monthly Digest of Statistics April 2012, p.9. Available from: http://www.census2011.gov.hk/pdf/ Feature_articles/Trends_Pop_DH.pdf. Accessed 3 Jul 2013.
16. Tuberculosis and Chest Service. Annual Report of Tuberculosis and Chest Service 2006. Hong Kong: Department of Health; 2008.

17. Census and Social Statistics Department of Hong Kong, 2006 Population By-census. Available from: http://www. bycensus2006.gov.hk/en/data/data2/index.htm. Accessed 3 Jul 2014.

18. Chan-Yeung M, Kam KM, Leung CC, et al. Populationbased prospective molecular and conventional epidemiological study of tuberculosis in Hong Kong. Respirology 2006;11:442-8.

19. Zignol M, van Gemert W, Falzon D, et al. Surveillance of anti-tuberculosis drug resistance in the world: an updated analysis, 2007-2010. Bull World Health Organ 2012;90:111119D.

20. Zhao Y, Xu S, Wang L, et al. National survey of drug-resistant tuberculosis in China. N Engl J Med 2012;366:2161-70.

21. Udwadia ZF, Amale RA, Ajbani KK, Rodrigues C. Totally drug-resistant tuberculosis in India. Clin Infect Dis 2012;54:579-81.

22. Wang L, Zhang H, Ruan Y, et al. Tuberculosis prevalence in China, 1990-2010; a longitudinal analysis of national survey data. Lancet 2014;383:2057-64.

23. Law WS, Yew WW, Leung CC, et al. Risk factors for multidrug-resistant tuberculosis in Hong Kong. Int J Tuberc Lung Dis 2008;12:1065-70.

24. Leung EC, Leung CC, Kam KM, et al. Transmission of multidrug-resistant and extensively drug-resistant tuberculosis in a metropolitan city. Eur Respir J 2013;41:901-8.

25. Hart JT. The inverse care law. Lancet 1971;1:405-12. 